This article was downloaded by: [University of Sydney]

On: 30 December 2014, At: 04:00

Publisher: Routledge

Informa Ltd Registered in England and Wales Registered Number: 1072954

Registered office: Mortimer House, 37-41 Mortimer Street, London W1T

3J H, UK

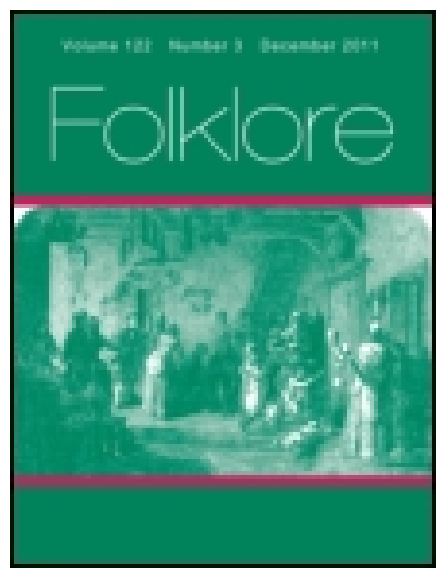

\title{
Folklore
}

Publication details, including instructions for authors and subscription information:

http:// www. tandfonline.com/loi/ rfol20

\section{Some Notes on the Huculs}

M. L. Hodgson

Published online: 06 Feb 2012.

To cite this article: M. L. Hodgson (1905) Some Notes on the Huculs, Folklore, 16:1, 48-55, DOI: 10.1080/ 0015587X.1905.9719436

To link to this article: http:// dx. doi. org/ 10.1080/0015587X.1905.9719436

\section{PLEASE SCROLL DOWN FOR ARTICLE}

Taylor \& Francis makes every effort to ensure the accuracy of all the information (the "Content") contained in the publications on our platform. However, Taylor \& Francis, our agents, and our licensors make no representations or warranties whatsoever as to the accuracy, completeness, or suitability for any purpose of the Content. Any opinions and views expressed in this publication are the opinions and views of the authors, and are not the views of or endorsed by Taylor \& Francis. The accuracy of the Content should not be relied upon and should be independently verified with primary sources of information. Taylor and Francis shall not be liable for any losses, actions, claims, proceedings, demands, costs, expenses, damages, and other liabilities whatsoever or howsoever caused arising directly or indirectly in connection with, in relation to or arising out of the use of the Content.

This article may be used for research, teaching, and private study purposes. Any substantial or systematic reproduction, redistribution, reselling, loan, sub-licensing, systematic supply, or distribution in any form to anyone is 
expressly forbidden. Terms $\&$ Conditions of access and use can be found at http://www.tandfonline.com/page/terms-and-conditions 


\section{SOME NOTES ON THE HUCULS.}

COMPILED BY M. L HODGSOX.

(See ants, p. 5.)

THE information which follows comes in the first instance from the fascinating account of the Huculs given by Professor Wlodzimierz Szuchiewicz of the University of Lemberg, Austria, in the three volumes of his work entitled Huculszcsyzna. This work is written in Polish, and is therefore to most Englishmen a closed book, although much can be learnt from the beautiful photographs and coloured plates with which it is filled. Through the extreme kindness and courtesy of the author, and the equally valued kind help of Professor Paul Postel of Lemberg University, who has spared no trouble in answering questions on the subject, I am able to give the Folklore Society some glimpses into the life of this most interesting tribe, chiefly gathered from the letters of my friend Professor Postel.

On the northern slopes of the Carpathians, in the Province of Galicia, live four Slavic tribes: the Gorale, the Lemki, the Bojki, and the Huculi. (The pronunciation is Hützüls.) The Górale, living in the valleys near the Tatra Mountains, belong to the Polish nation, and are Roman Catholics, the other three tribes are Ruthenians, and belong to the 'Greek Church. The Huculs are without doubt the most interesting of these tribes, and have preserved to this day their ancient customs and original dress. They live near the frontiers 
of Hungary and Bukowina, in the eastern part of the Carpathians, in the valleys of the Prut and Czeremosz, in a part of the country called Pokutia, formerly the object of continual struggles between the ancient kingdom of Poland and Wallachia They number about 60,000 . including 2000 Jews. The Jews have of late years settled in the villages, and introduced brandy to the tribe, at the same time taking from them many cottages and much land.

The tourist visiting the picturesque valleys of the Czeremosz and upper Prut will from time to time meet shepherds and country people whose gaily coloured dress necessarily attracts his attention. The Huculs like gay colours, especially red, which contrasts extremely well with the green background of forest and meadow. These simple people live on what their cattle and fields afford and wear clothes made by themselyes from the wool of their sheep, or threads of their own hemp. Caps and shoes are also of their own peculiar make, and only to be seen amongst them. These good and simplenatured people would be quite independent and content were it not for the Jews and the military system. The latter forces their boys to spend some years abroad, and when they return, they bring back the vices of the large towns, as well as diseases previously unknown. The small horses, which carry their riders safely over most perilous mountain paths, are beautiful little animals. Both men and women ride astride, and the latter are generally seen complacently smoking their pipes in conpany with the men. The Huculs, having been formerly very wealthy, were able to satisfy their love and taste for fine and beautiful things. Many of them possessed extensive pastures, some 30 to 40 horses, and large herds of cattle, with hundreds of sheep. Everywhere in his mountains the Hucul felt free and self-dependent, like the Kosak in his steppe. The waters of the Prut carried 
the timber from the mountains as far as Odessa; and Armenian merchants brought them beautiful weapons from Hungary or Constantinople.

These happy times have passed away; the levelling modern institutions of school and the military system have proved unpropitious. To-day, owing to these courses, and more particularly to the settlement of Jews in their midst, one can hardly find one rich Hucul. All these circumstances have contributed to the fast decay of his wealth and his pride, and some twenty years ago the finishing touch was put, when the railway from Lemberg through Worochta to Hungary was opened.

The imaginary world in which the Hucul lives still differs widely from the real one. He believes that the air and surface of the earth are inhabited by innumerable spirits (night-spirits, forest-spirits, etc.). $\mathrm{He}$ is extremely pious with regard to religious observances and ceremonies, although his morality would not be approved by an Englishman. On rising in the morning he makes the sign of the Cross three times, and recites a prescribed prayer. The same is done on going to bed and before and after every meal. When leaving his home he makes the sign of the Cross on the threshold of his room. Not only does he celebrate the numerous feasts. prescribed by the Greek Church, but also those of Saint George, Elijah, and other saints. Many ceremonies which . have been brought down from pagan times are observed on these days besides the religious ones, and even the religious ones are for the most part pagan in origin. Fasting in Lent is observed with the utmost rigour. For forty days the Huculs, as well as all other Ruthenian peoples, forego all meat: especially conscientious in this are the young girls, as they are persuaded that fasting assures them an early marriage.

Pagan creeds have so mingled with Christian ones that the latter are often degraded. A general belief is. 
PLATE I.

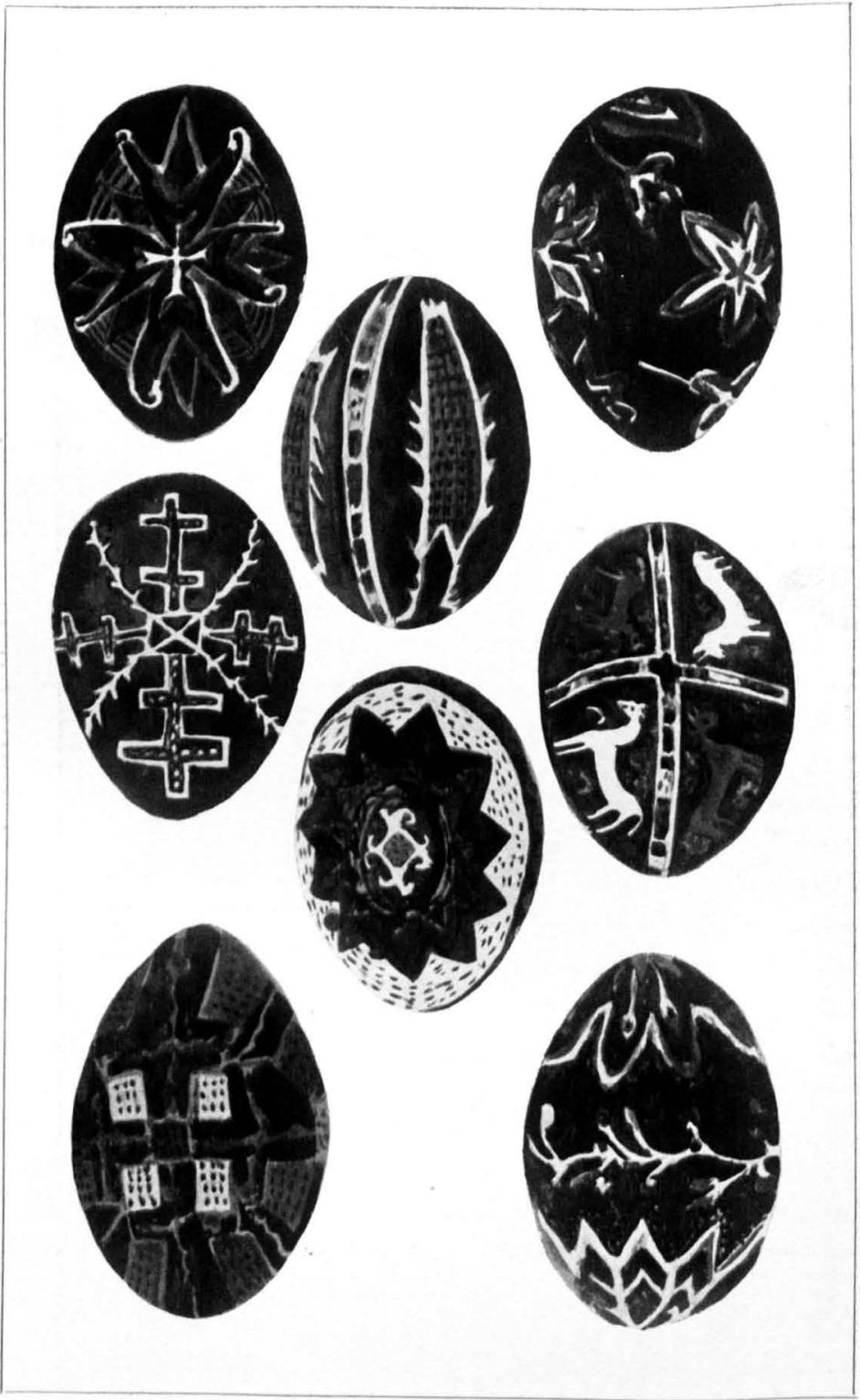

HUCUL EASTER EGGS.

(Sce page 53.)

To face p. 50. 


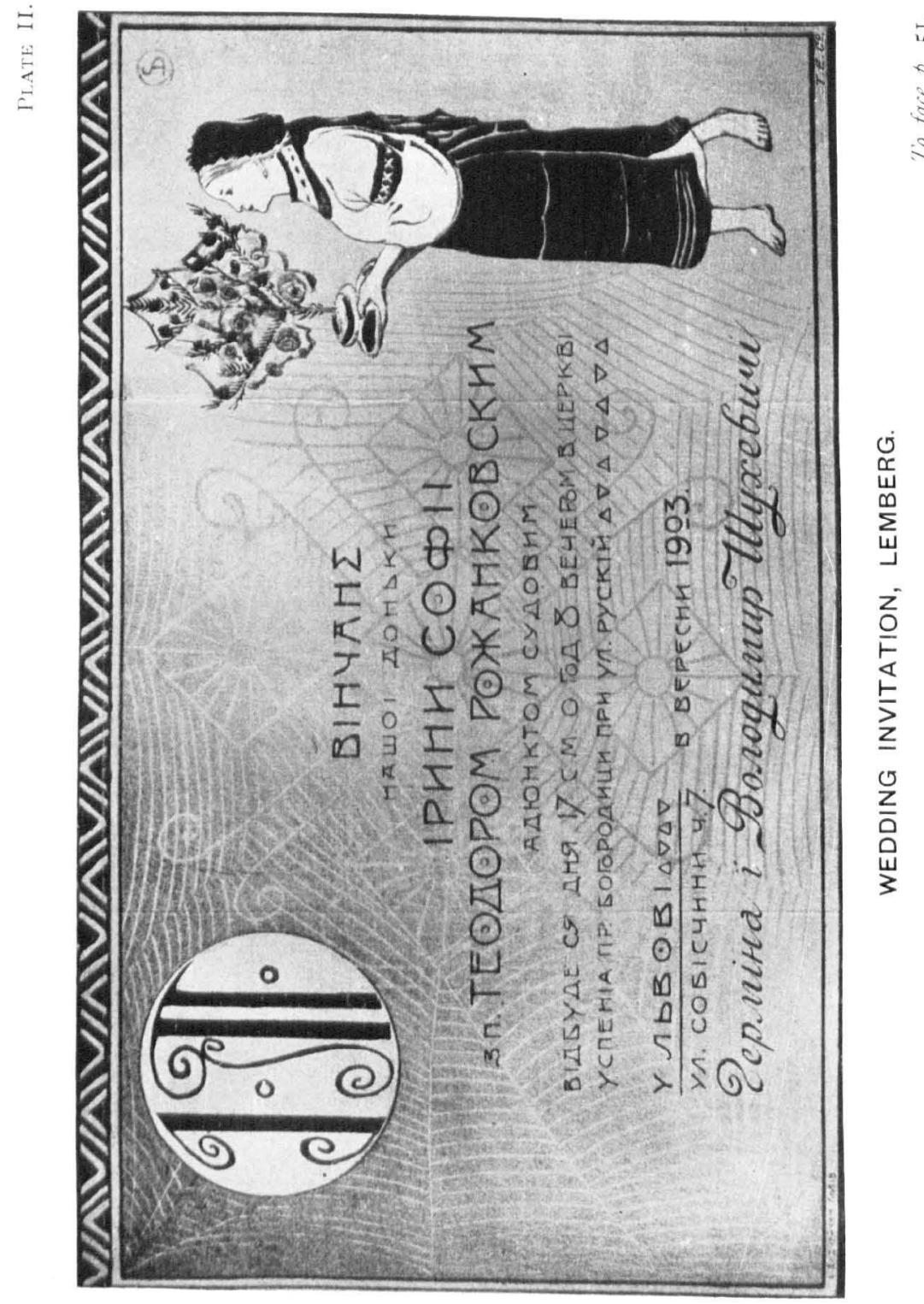


that the Mother of God and the Holy Virgin are two persons. All changes and accidents of everyday life are attributed to spirits. They will drink the milk of the cows, lull to sleep those who should be on guard, cause trees to fall; they thunder and send the lightning, and such like things. Of great interest is the remnant of belief in a good and bad god, the latter being called Arinyk. Much could be said about their strong belief in witchcraft did space permit.

The Huculs have their own cosmogony, which is exactly similar to that preserved among the inhabitants of the Ukraine in Russia. Professor Szuchiewicz, of Lemberg, who has spent more than twenty years in collecting ethnological material and objects connected with the Huculs, is about to publish the 4th volume of his work, which will contain the cosmogony and other traditions of the highest ethnological interest.

\section{MarRtage Customs.}

The leaves of the berwinck (vinca minor) are of great importance during the wedding. festivities of Huculs as well as of Ruthenians. The wreaths of the young couple are made of, and the dishes omamented with, these leaves, in the same way that the myrtle is used in Germany. Besides this, a small fir-tree is decorated and richly ornamented with variegated gay, shreds of paper, red and white wool, flowers, golden threads, and so on. This little tree is always carried before the bride and bridegroom by one of the most respected husbandmen of the village, who regards this office as one of great honour. He carries it before the couple on going to and coming from the church and cottage where the wedding festival takes place. Here he puts it on the table before the places of the nuptial pair, where it remains till the end of 
the marriage ceremonies, sometimes lasting for 8 or ro days. After this the tree is nailed to the gate of the farm, where it stays till wind and rain have destroyed it. On the reproduction of a wedding invitation (Plate II.), ${ }_{1}^{1}$ it will be noticed that, by the caprice of him who drew it, a girl carries the fir-tree.

There are a great number of wedding songs which play an important part in the festivities. Another custom before the wedding is, when the youth who is courting sends his match-makers (generally esteemed friends of his family) to the house of the girl. In proof of their good breeding they will not fulfil their commission in plain words, but they will begin by relating a tale of a hunter who pursued an otter, which leapt into a pond, and from thence into the house in which they. are. During this preface, the parents of the girl prepare a luncheon, consisting of wheat bread and whisky (vodka), while the girl gives them a piece of needlework prepared by her for the bridegroom. Finally the suitors give their message in form. After the marriage, which takes place in the Greek Catholic Church at 8 o'clock in the morning, the bridegroom returns with his guests to his father's house, and the bride to that of her parents. In both houses the wedding is celebrated. It is not until the guests have well eaten and drunk that the parents of the bride will send a deputation of good friends to the house of the bridegroom to conduct him to his new lodging. Sometimes the case may be reversed, if the young couple are to live in the house of the bridegroom's parents. When begging him or her to betake themselves there, they will offer "white" bread, the Hucul name of which is Kotacs.

2The invitation runs a follows: "The marriage | of our danghter | Frena Sophis | with Mr. Theodor Rosankowski, Judge [adjunkt sgdowoy] | will be held the $17^{\text {th }}$ inst, at $8^{4}$ evening in the church in Iwow [Lemberg] | Sobiestexyara Street. 7 September 1903. | Hermina and Wolodimir Szuchiewick" 
Plate III.

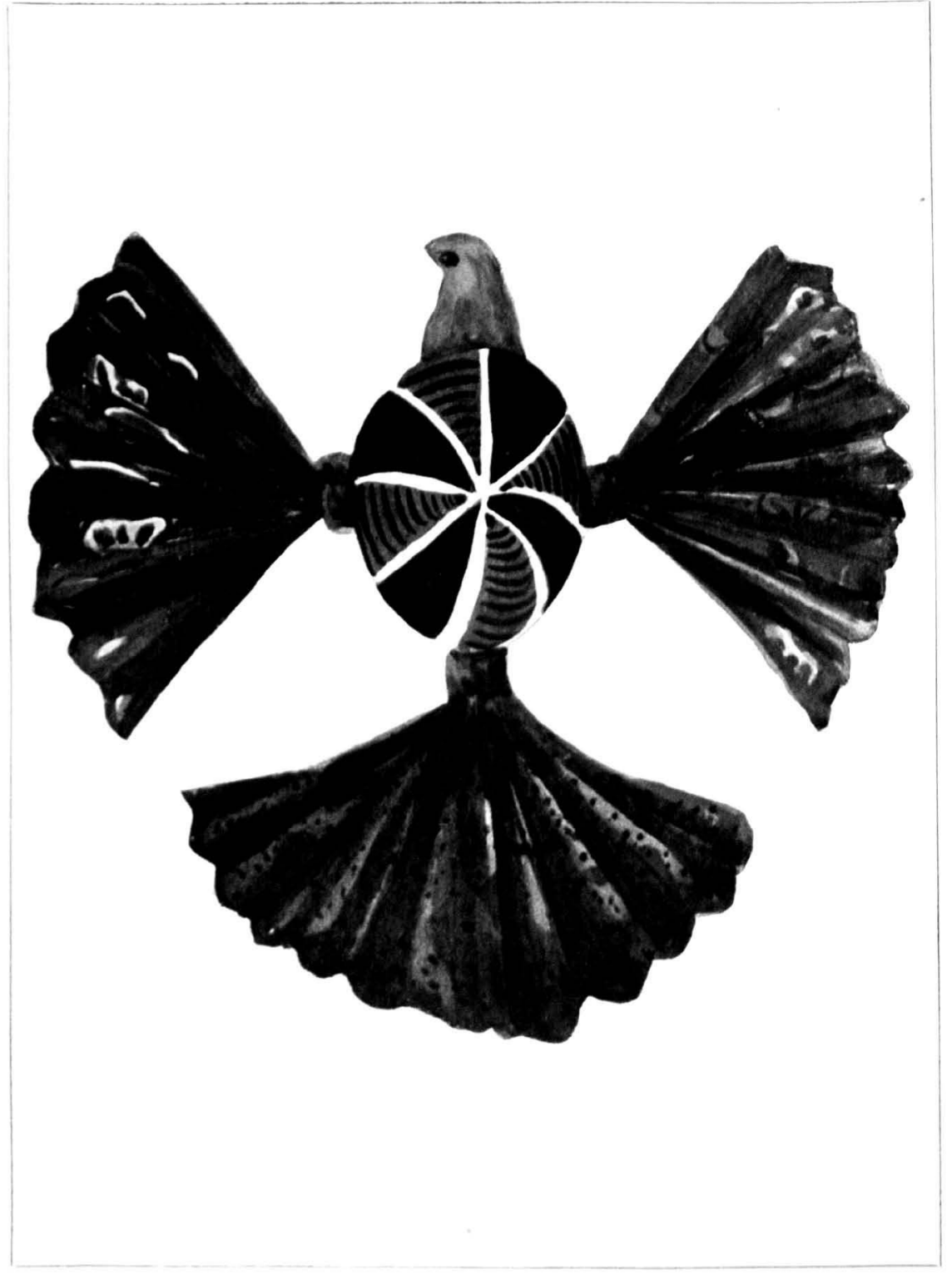

HUCUL EASTER DOVE.

To face p. 52 . 
PIATE IV.

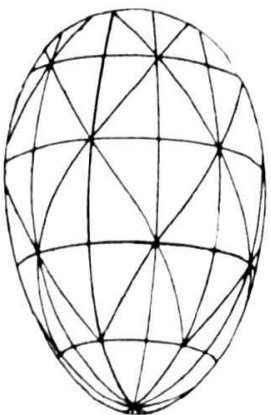

1.

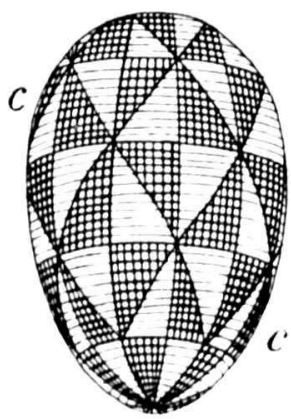

1.

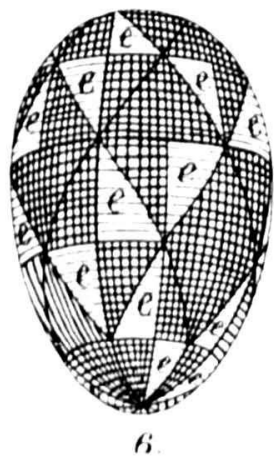

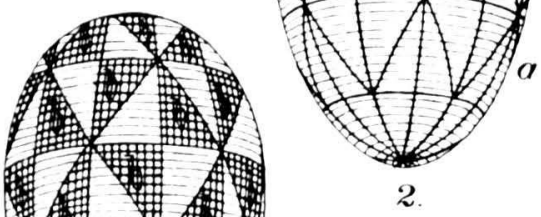

a
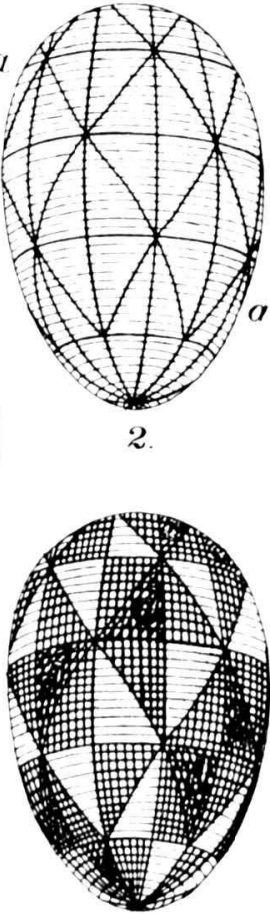

5

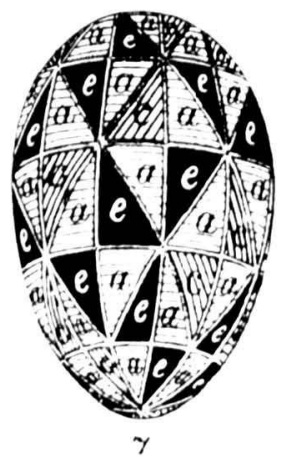

PROCESS OF COLOURING HUCUL EASTER EGG ILLUSTRATED,

To face t. 53 . 


\section{EAster Eggs.}

In the Hucul villages the people assemble before the church on Easter Day at four o'clock in the morning in order that the Easter bread, ham, etc., may be blessed by the priest. After this ceremony, many of them present each other with painted eggs, mutually asking forgiveness from each other. In the afternoon the boys try to take the eggs from the girls. If any girl offers a boy an egg of her own accord, he knows that she wishes him to court her. Birds (doves), represented by means of eggs, are fastened to the ceiling, so as to hang down in the living room of the cottage in remembrance of the birth of Christ (Plate III.). They say that then a dove came down from heaven soaring over the child Jesus. The series of eggs in the illustration (Plate IV.) represent the stages in the technical drawing and colouring of them. On the first egg are only wax lines, which, after the final touches, will be removed, leaving the egg white. Secondly, the egg is put into a yellow colour; those parts of the egg which are to remain yellow being in their turn covered with wax, and so on.? (See also Plate I.)

The yellow colour is made from the dried blossoms of genista tinctoria, and must be gathered before the feast

3The body of the dove is made of a coloured egts-ahell, the wings and tail of figured paper, very evenly folded, coloured only on the upper sides; the bead and attachment of wings and tail are made of grey wax.

Fig. 2. Egg covered with intersecting lines in wax, eventually to show white.

2. Dipped in yellow dye (a).

3. The parts intended to remain yellow corered with wax (b).

4. Coloured green (c), the wax Indicated by cross-batching.

5. The green parts covered with wax (d).

6. Dipped in red dye (e).

7. The max removed, and the hidden colouring thown $(a, c, a)$, the interecting lines white. 
of St. John (7th July, according to the Greek calendar). The dark green and violet colours are made from the rind of the seeds of Helianthus annus and the berries of Sambucus nigra and the bark of the alder-tree. While making these colours and drawing the designs, a great many rules and rites have to be observed, in order that these pisanki (from pisac, "write," because they are "written" with wax by means of a pencil') may be without any witcheraft. As was before noticed, pagan traditions and customs have become closely connected with forms of divine service since the Huculs have been shut off from the world in their mountains; but there is small doubt that since they have been "discovered" many of their original customs and traditions will alter.

Were it possible to have a German, French or English translation of Huculsecryszra, it would doubtless be warmly welcomed by all lovers of folklore.

The objects figured in the plates are from the collection of Professor Szuchiewicz, and were all exhibited by me at the Society's meeting on January 18th.

\section{PLATE V.}

I. Specimen of wood carring.

2 and 3. Neclelaces wom by girle

4 and 5 . Neckleces worn by women.

6 and 8. Backles worn at the neck.

7. Carred box inlaid with brass

The egs-pencil is made of a small piece of stick, four or five inches long, with a tiny bress tube thrust trensvereely through it at one end. A bit of wire is fitted into the trbe, and projecting at one end makes a fine, hard, yet elastic point, with which firm and decided lines can be drawn in wax on the egge. 


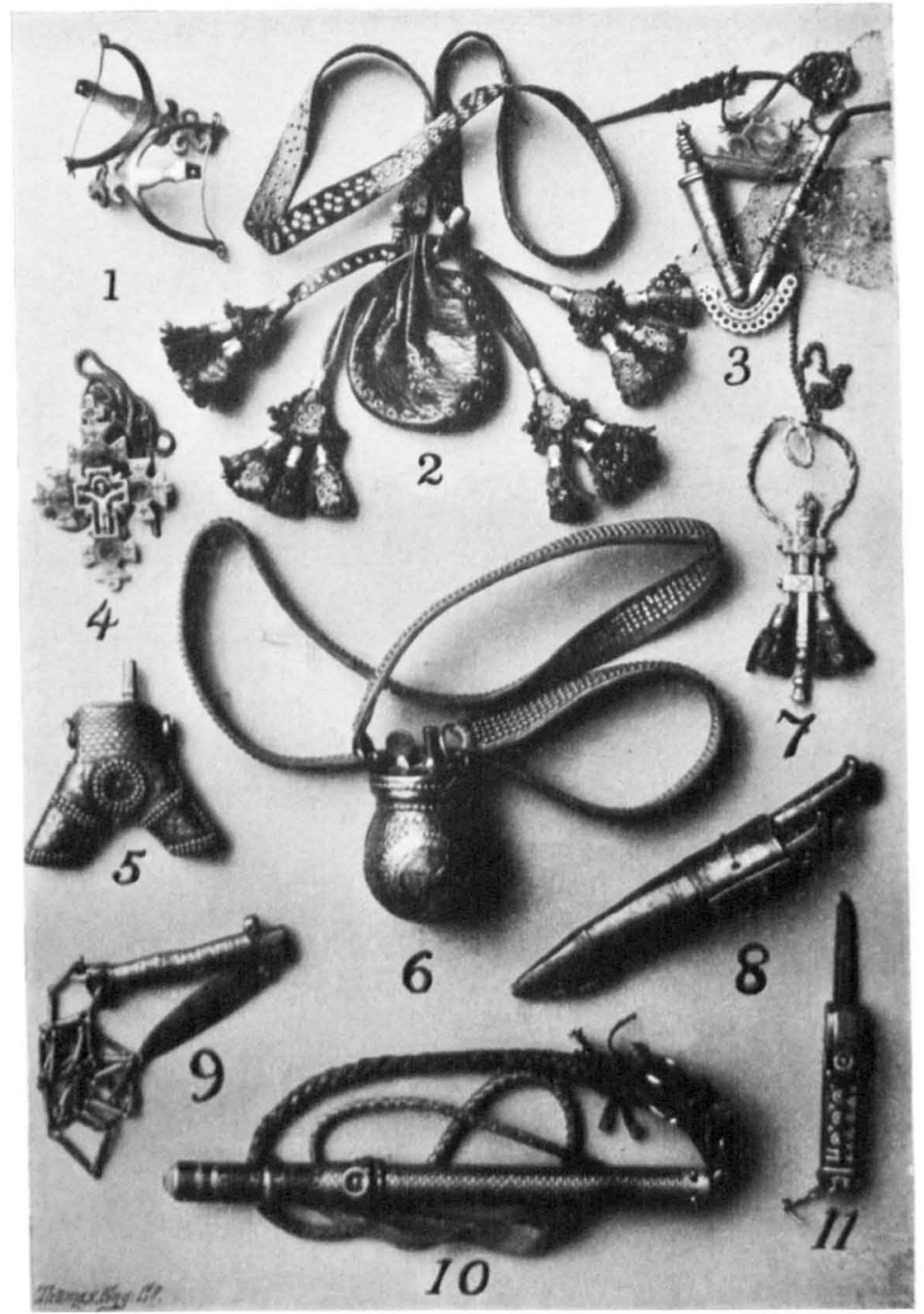

IMPLEMENTS OF THE HUCULS. 


\section{PLATE VI.}

1. Heel ornaments (?).

2. Purse made of leather and ormamented with thimbles

3. Pipe, cleaner, and steel.

4. Man's crose of brass

5. Powder horn.

6. Powder flask and strap.

7. Man's needle-box, worn in full-dress and attached to the broad belt, in which knives, etc, are placed.

8. Knife and steel in brass sheath.

9. Knife.

10. Riding-whip and stick.

11. Knife, the handle of which is inlaid with beads.

M. L. HODGSON. 